\title{
Succession Planning Best Practices for Large and Small Organizations
}

\author{
Yasmeen Bano \\ Siti Sarah Omar \\ Fadillah Ismail \\ Faculty of Technology and Business Management, \\ Universiti Tun Hussein Onn Malaysia(UTHM), \\ 86400 Parit Raja, Batu Pahat, \\ Johor, Malaysia
}

DOI: https://doi.org/10.36941/mjss-2022-0o13

\begin{abstract}
Developing potential candidates for organizational sustainability and business continuity is emerging as a priority in any organization. Every organization small or large is facing or will face challenges for the immediate future successor with the right people. Top management can create surroundings which allows leadership development with the help of succession planning internally. Succession planning is an enterprise approach that has gained a lot of interest in all organizations because of excessive demand for holding knowledge and the shortage of skilled workforce. The study has been done by using standard systematic literature review method. The current study focuses to provide comprehensive review of best succession planning practices followed by all type of organizations. The major purpose of this article is to describe the standard best practices of succession planning in any organization. This study will provide enough evidence to use succession planning as an instrument in the organizations in recruitment process, employee retention strategies and top management future development within the organization.
\end{abstract}

Keywords: succession planning best practices, literature review

\section{Introduction}

The practice of succession planning in the private organizations is more than public organization. Similarly, nonprofit organizations lack the formal succession planning practices effectively. The importance of succession planning within both academic and business organizations is evident (Crean, 2011; Green, 2011; Grossman, 2014). Several researchers have been conducted studies about succession planning in the last decades. However, Henry Fayol (1841-1925) a French innovator was the first scholar who identified the need for succession planning. The leading organizations have adopted formal succession planning in the late 196os and early 1970s. The most relevant study in succession planning was accomplished by Trow (1961).

Today, organizational system is challenged by the lack of consistent workforce planning which has affected the strategic succession planning for top management as well as a middle management employee. High turnover workforce is a big concern in many countries in all type of organizations. 
Succession planning is unexpectedly turning into a key strategic planning device for human resources management to develop a plan for the inevitable succession of key employees and managers at all levels. Succession planning is intended to help the organizations in managing and retaining their talent pipeline (Bolander et al., 2017) and focusing on the competence development (Arokiasamy et al., 2015). Most of the organizations do not focus to identify successor in advance. Some organizations devote their effort to develop a strong pool of candidates. When the need arises, the strongest candidate become a successor. The present study focuses to provide comprehensive review of best succession planning practices implemented by all types of organizations. The major purpose of this article is to illustrate best practices of succession planning in organizations.

\section{Literature Review}

Most of the literature has been focused on private sector as compared to public sector and nonprofit organizations. According to the study of (Muhammad and Meherbani,2011) Initially literature review on succession planning was done by Kenser and Sebora (1994) which was published later between 1960 and 1993 (Muhammad and Meherbani,2011). The study of Kenser and Sebora (1994) showed most of the focus was on external and internal successor. This study concluded that this period was only the beginning of a comprehensive of study of succession planning. The study of kenser and Sebora (1994) also found that only three studies were done for nonprofit organization's transition process. The study of Santora and Sarros (1995) also suggested to more studies need to be done for nonprofit organizations. The results of the study of Mateso (2010) identified that health institutes also not take seriously about succession planning. In addition to this, the study of (Rubin, Illia,2007) in the construction sector found that a formal succession planning does not exist in some organizations which can cope with the increasing number of aging population and retiring founders.

Similarly, few studies have been conducted on higher education succession planning processes that needs immediate attention (Campbell, 2002; Heuer, 2003; Hull, 2005; Mackey, 2008; Weiss, 2005). Although corporate industry is doing relatively doing well in succession planning processes (Mateso, 2010), but still succession planning challenges are notable in all kinds of organizations. Some studies mentioned that few organizations do not have written succession planning even when their CEOs are nearing departure (Hutcheson, 2007). Although corporate industry is doing relatively better in succession planning processes (Mateso, 2010), but still succession planning challenges are notable in all kinds of organizations.

The study of Hawkins\& Kingsberry (2018) mentioned that educational literature suggests that in some districts, succession planning agendas may be in direct conflict with professional development planning for organizational leaders. In the health sector many institutes prefer to hire experienced nurses as compared to new graduates to fill vacant positions (Mathe et al,2017). Research on succession planning shows that beginning to prepare for leadership transition before it occurs can minimize potential negative impacts (Sullivan \& Perrenoud, 2017).

\subsection{Succession Planning and Replacement Planning}

Ideally Succession planning is a systematic approach that helps the identification of job vacancies which are vacant due to turnover workforce or a retirement. The traditional approach of succession planning has taken a replacement planning which focus only on executive level vacant positions. With traditional approach one or two successors might be identified and selected based on the feedback from their immediate supervisor and placed on the fast track into upper-level position. Succession planning is a very common approach for CEO position but is undoubtedly also applicable to all other levels of employment. It is concluded that succession planning is not only limited for top management.

Armstrong (2003) defined Succession planning as a process in which organizations can make sure that staff are being hired and constantly improve their skills to fill the competent key roles in the organization. Dessler (2005) identified process of succession planning process in three important 
steps which includes identifying and analyzing key jobs, individual assessment, and the selection of right person for right position. Rothwell (2005) explained that those organizations face problems in major areas such as turnover who do not have formal succession planning. Ultimately these organizations lack the essential skills for key positions. Succession planning is a process by which one or more successors are identified for key posts (Kolhatkar and Banerjee, 2015).On the other hand, there are some researchers such as Fibuch (2012) and Ibarra(2005) who divided succession planning process in to three main components. The first component is selection of candidate based on previous experience and formation of pool. The second component is the role of successor, and third component is change management.

Some organizations are confusing with the term of succession planning and change it with replacement planning. The definition of replacement planning is considered as a process of identifying short-term or long-term backups so that organizations have people who can assume responsibility for critical positions during emergencies (Rothwell, 2011). The short-term replacements focus on finding employees for a shorter period such as sick or on vacation. While long term replacement planning identifies employees' backups for longer period such as sudden loss of an employee. Replacement planning is essentially disaster planning in a form of is form of risk management (Rothwell, 2010). Most of the organizations focus hiring process on replacement filling. Replacement planning usually identifies one individual from within the organization till they find the suitable candidate to fill the position.

The difference between succession planning and replacement is very clear. As a result, replacement planning is not the substitute of succession planning. Although, Succession planning has developed gradually into a process that can be used to identify qualified employees for current vacant positions as well as for future. Moreover, succession planning aims grooming for the talent for the future and replacement planning is more willing to filling vacancies. Finally, the active development of successors is more likely to be found in succession planning than in replacement planning (Wiesman, 2012). A replacement plan ensures the continuity in the operations of business and focuses on filling the positions within a shorter time whereas succession planning develops talent pool.

\subsection{The Need of Succession Planning}

Employee's retirement planning and timing have important implications for all kind of institutions. Unplanned early or late retirement can create direct consequences for human resources department. Replacing experienced employee with inexperience employee can be difficult. The most common age of retirement for public employees is in between 60 to 65 . On time retirement refers to the conventional age of retirement, that is, at or around age 65 (Silver et al, 2016). There are several types of retirements such as baby boomers' retirement, delayed retirement, earlier retirement and expected retirement. Apart from retirements positions can be vacant due to emergencies such as sudden death, resignations, and terminations. The following subheadings explained the importance of succession planning for any organization.

\subsubsection{Vacant positions due to unexpected events}

Organizations need to be prepared for unexpected events such as death, illness, termination, resignations, and promotions. Succession planning is a systematic approach which is ready for unexpected events.

\subsubsection{Vacant positions due to baby boomers Retirements}

The large number of baby boomers creating big risk for many organizations. These risks include loss of organizational knowledge, skills, and experience. The number of potential retirees is growing due to baby boomers. When baby boomers start thinking to leave the organization, there will be urgent 
need of filling position. Similarly, when baby boomers are heading into their retirement years, most of the organizations do not have a signed succession plan. Succession planning only ensures these replacements are prepared to be promoted on shorter time (Ibarra, 2005)

\subsubsection{Delayed Retirement}

Some employees decide to postpone retirement due to financial obligations, Career satisfaction and institutional flexibility. These factors can be given importance to discuss during the succession planning process.

\subsubsection{Expected retirement}

The number of potential retirements is also increasing due to expected retirement age. The role of human resources department is to keep tracks of all expected retirements for near future.

\subsubsection{Internal Vs External Successor}

The selection of internally or externally successor is another major concern. Some organizations find it more rewarding to promote internal successor, while other organizations prefer to recruit externals. Organizations face problems when the technical and specialized positions become vacant. Internal recruitment encourages employees in public organizations for giving promotions annually. Furthermore, internal recruitment makes the recruitment process easy and simple when senior employees leave organization.

Recruitment of external employee can make the process slow and can lead to conflict among the existing senior staff. It is also costly and according to (Bercherlmann, 2005). Since some organizations (example; higher education institutions) has specialized and technical vacant positions. This kind of planning may provide an opportunity for public institutions to identify talent within organization. Some organizations find it more rewarding to promote a successor from within, but some organizations prefer externally. Some experts believe that all successors from within is dangerous since this practice tends to limit internal management style.

\subsubsection{Labor shortage}

Workforce shortage with retiring employees can create substantial pressure for some sectors in many countries. The lack of effective and skilled leaders has been noted as one of the biggest business risks of the twenty-first century (Miodonski \& Hines, 2013; Chassiakos, 2014; lyles, 2019). However, technical skills alone are not enough to warrant leadership promotion (Sonnino, 2016). In early 1980 recession caused a disruption in the workforce, with upper management layoffs and the elimination of talent development practices (Cappelli, 2008; Cappelli \& Keller, 2014; Cascio, 2014).

\subsection{Previous Studies of Succession Planning}

Several researchers have been conducted different studies in the past decades, however succession planning has been adopted formerly in the late 1960s and early 1970s. Few empirical studies of research have been done in between 1959 to 1960. The most relevant study in succession planning and management in the 1970 (Meherbani and Mohmad, 2011). The most relevant only study during 1970 to 1979 was about manpower planning (Coleman, 1970).

Succession planning gained great attention for formal succession planning which involves management development and CEO Succession (Zaich, 1986; Kesner and Sebora, 1994). A survey done was to examine management succession planning development practices (Walker,1984). Previous researchers in 1980 os focused on succession frequency associates with CEO succession (Kim, 
2010). The need of succession planning, leadership pipeline concept was defined by Mahler ,1983). The study of Meherbani Mohmad (2011) identified the necessity of succession planning. The research in this period expanded to different sectors such as higher institutes, government agencies, health sector, and nonprofit organizations.

Seven-pointed star model was developed to achieve a systematic succession planning and management (Rothwell, 2001). Assessment of the role of succession planning in corporations and its effect on women's promotions (Stroud, 2005). The study of Succession planning in healthcare organizations examines how the healthcare organizations identify the potential leaders, to address succession plan, retain employees and prepare for workforce diversity (Shipman, 2007). The study of Mandy (2008) introduced some indicators for succession planning which include ability to identify new leaders and the ability to sustain core competencies.

Some researchers focused on some others succession planning best practices. The study of Deshwal (2015) emphasis on the transparency of succession plan which based on individual roles rather than jobs. Many organizations discuss succession planning only when they need to replace some personnel. The study of Deshwal (2015) suggested best practice of external hiring for a need of new blood in the organization. Replacing employees and not developing them has become big and common mistake by organizations both in developing and developed nations (Kehinde \& Nwachukwu, 2017). Managers need to consider an individual backup plans for short to long-term absences as well as permanent departs (Bratcher, 2018). The current Study of Payne et al. (2018) shown that conducting annual talent reviews are important for assessing and ensuring a deep pool of internal talent (Collins et al. (2016); Groves, (2017); Trepanier \& Crenshaw (2013). This can be accomplished by finding out the key leaders, competencies development, capture of knowledge and monitoring, evaluation of metrics. This would result in effective succession plan as well as retain operational stability.

\subsection{Succession Planning Best Practices}

Many researchers have been identified best practices applicable in the field of succession planning (Rothwell,2010,2005, Verman and Gandossy,2006). Succession planning practices involves having a support system with senior management and involving the line managers in recognizing potential candidate and integrating the succession management plans with the business strategies (Stadler, 2008). The study of Aswathappa (2013) emphasis ,succession planning practices must be implemented after recognizing the individual needs. This paper focused on the best practices identified by famous researchers William Rothwell, Robert M. Fulmer and Chief Executive Magazine April 2004.

Table 1: Summary of The Key Best Practices by previous Authors

\begin{tabular}{|c|c|c|}
\hline Best Practices of Robert M Fulmer & $\begin{array}{l}\text { Best Practices of William } \\
\text { Rothwell }\end{array}$ & $\begin{array}{l}\text { Best practices of Chief Executive } \\
\text { Magazine }\end{array}$ \\
\hline $\begin{array}{l}\text { Deploying Succession Management Process } \\
\text { Link between succession planning and business } \\
\text { strategy. } \\
\text { Role of human resources for developing tools and } \\
\text { processes of systems } \\
\text { Role of technology for the facilitation of process }\end{array}$ & \multirow{4}{*}{$\begin{array}{l}\text { Roadmap Model } \\
\text { Involvement of CEO and senior } \\
\text { management } \\
\text { Implementation of effective } \\
\text { performance management system } \\
\text { Ethical standards descriptions such } \\
\text { as values, norms. } \\
\text { Shared resources } \\
\text { Leadership development for shared } \\
\text { competencies. }\end{array}$} & $\begin{array}{l}\text { Identify } \\
\text { Identify criteria for candidates }\end{array}$ \\
\hline $\begin{array}{l}\text { Identifying the Talent Pool } \\
\text { Focus on future leaders } \\
\text { succession management competencies. }\end{array}$ & & $\begin{array}{l}\text { Diagnose } \\
\text { Individual's candidate's strength and } \\
\text { weaknesses }\end{array}$ \\
\hline \multirow{2}{*}{$\begin{array}{l}\text { Engaging Future Leaders } \\
\text { individual development plans for all employees } \\
\text { Coaching and Mentoring } \\
\text { Traditional education programmes such as special } \\
\text { assignments. }\end{array}$} & & \begin{tabular}{|l|} 
Prescribe \\
Right development for organization
\end{tabular} \\
\hline & & $\begin{array}{l}\text { Monitor } \\
\text { Assurance of succession planning } \\
\text { process in the organization. }\end{array}$ \\
\hline
\end{tabular}

Source: Rothwell, W. J. (2010). Effective Succession Planning: Ensuring Leadership Continuity and Building Talent from Within. 4th ed. New York: AMACOM. 


\subsubsection{Best Practices According to Fulmer}

The following best practices for succession planning are recommended by Fulmer (2004)

\subsubsection{Link between succession planning and Business strategy}

Organizations that have best practices of succession planning have link between operation continuity and succession plan. This link gives succession planning the opportunity to affect the organization's long-term goals and objectives (Fulmer, 2004; Rothwell, 2010)

\subsubsection{Role of Human resources}

The contribution of human resources department in the succession planning process is important ,but not during development phase. The only responsibility comes to human resources department during the implementation phase. The role of human resources is very critical during the process of workforce planning. This process involves identifying and analysing the need of human resources to meet the organization needs (Pynes, 2004).

\subsubsection{Role of Technology}

The role of technology is very basic element in the succession planning process. Ideally, technology facilitates the process rather than becoming the focus of the process. It helps the process in terms of making it shorter, simple, or even more flexible (M. Fulmer, 2004). "Many organizations are in a competitive race to enter e-commerce High-tech (example: video conferencing or audio teleconferencing) and online (example ; intranet or extranet)approached had a dramatic impact on succession planning practices“ (Rothwell, 2010, pg 272). Some organizations are in a competitive race to use of technology to deliver programmes. A combination of internal and external resources to deliver the programmes content could also be useful (Leskiw \& Singh, 2007). Some organizations use organisation's succession management website to assess employees' current potential level, skills, and experience. They use it as a reporting tool as well.

\subsubsection{Identifying Talent Pools}

Organizations make continuous effort for identification of future leaders. Many organizations cannot find a successor in advance. In this situation organizations devote their efforts to develop strong pool of candidates, from which successor can be selected when need arises. The strongest candidate at that time becomes the successor (Fulmer, 2004, Rothwell,2010)

\subsubsection{Individual development Plans}

The growth-oriented organizations take actions on the importance of individual development plans for all employees. Individual development plans identify developmental activities are needed and the best practice firms typically have a mechanism in place to make it simple for the employee to conduct the developmental activities ( Rothwell,2010). The responsibility of human resources department is to monitor employee's development activities (Fulmer, 2004). Individual Leadership development focus on the skills and abilities.

\subsubsection{Fundamental development activities}

Best practice partners rely on the fundamental development activities of coaching, training and development most frequently and utilize all development activities to a much greater extent than sponsor organizations (Fulmer, 2004) 


\subsubsection{Traditional education programs}

In addition to traditional excessive education programmes, best practice partners increasingly use specific assignments, action learning and web-based development activities (Fulmer, 2004). The selection of special assignment chosen is supposed to present a challenge to the participant and improve their analytical ability (Deshwal, 2015)

\subsubsection{Best Practices According to William Rothwell}

William Rothwell (2010) has identified the following succession planning practices.

\subsubsection{Roadmap}

Succession planning must go beyond simple identification of internal development of leaders. The strategic roadmap is necessary to develop future leadership. Succession management programmes can help beyond identification of leadership development. Devoting funds to internal leadership development is the central way to maintain organizational sustainability.

\subsubsection{Top leadership involvement}

The role of CEO is very strategic (Redwan, 2017). The involvement of CEO guarantees the succession planning process is on right track and implemented well. Hence the role of CEO is essential during succession planning process. Organizations need to know the type of talent requires for vacant positions. It is essential to construct a lifestyle with the involvement of top management and personnel that helps and reinforces shared accountability, comments mechanisms and the general significance of leadership improvement (Leskiw \&Singh, 2007).

\subsubsection{Develop and impellent an effective performance management system}

Employee's assessment is depending on the organizational need and culture. Some institutions have effective assessment tool for measuring all employee's performance.one famous assessment method is 360-degree evaluation which evaluates employees from supervisors, peers, and subordinates. This evaluation method is very helpful for evaluation top positions leaders. With the help of this evaluation method internal developed candidate may get effective results from the direct supervisor but might poorly results from peer and subordinates.

\subsubsection{Competencies for strategic objectives will be needed}

Organizations identify the need of competencies to achieve strategic objectives for selection of successor.

\subsubsection{Narrow development gaps by individual development plans}

The success of most organization is depending on two main things. Firstly, the young talent candidates developing them in future positions. Secondly, replacements for retiring employees' transition plan timely for the continuation of leadership. Designing well-developed programmes such as trainings and education can help new employees mentoring. It is very important for all organizations and employees to know the employee's development programmes and selection of successor seriously. 


\subsubsection{Assess employees with competencies and develop ethical standards}

A strong organizational culture provides values, beliefs and standards for all employees which affect effective succession planning. These values provide regular guidelines on everyday business continuity.

\subsubsection{Shared resources for all employees.}

Best practices in the succession planning include developing entire system for all employees with the help of formal training and action learning activities. building a viewpoint that talented employees are sharing different resources instead by benefiting some specific managers. This development device can allow man or woman employees and managers to develop together by sharing resources.

\subsubsection{Use leadership development efforts to build shared competencies needed for the future}

Developing professorial competencies is a key to future organizational success. Succession planning is the deliberate and systematic effort made by organizational management to recruit, enhance, and retain men and women with a range of management talents successful of enforcing contemporary and future organizational dreams (Leibman et al., 1996; Rothwell.2010)

\subsubsection{Best Practices According to Chief Executive Magazine}

The following four key best practices according to Chief Executive Magazine, April 2004 are as follows:

\subsubsection{Identify}

Identification of candidate for leadership roles is key issues in the succession planning process. It involves objective criteria and consistency to identify candidate. It is important to identify future leaders based on higher potential rather than higher performance (Leon, 2016). High potential leaders can stay longer in the organization.

\subsubsection{Diagnose}

Once identify the right candidate, the next step is to assess individual's strength and weaknesses according to need of organization. The most important step in succession planning is to create a culture which encourages individual strengths and provide opportunities to improve weaknesses. Hanson (2013) indicated that formal knowledge requires for succession planning process. The process involves, talent development, grooming potential leaders, talent reviews and monitor results.

\subsubsection{Prescribe}

Coaching from senior management allows high potential employees to learn about key issues in the organization about the future direction of organization. Current leaders can drive successful development skills and competencies. Leaders want the integral expertise to effectively lead complicated environments and agencies (Hess et al., 2014)

\subsubsection{Monitor}

Organizations who exercise succession planning and management development have to understand to set up a monitoring gadget for imperative personnel improvement (Eskierka, 2011). More advanced 
dimension purposes such as monitoring employee engagement and employee performance need to be implemented.

\section{Methodology}

This review paper is based on the extensive systematic literature review search of published articles which primarily address the concept of succession planning and best practices in the different organizations. Peer reviewed articles published from 1950s to 2019 are included which are focused on the study of succession planning practices in the different sectors such as health, education, family business and construction sector. The results of the systematic literature review indicate that most of the organizations are aware about implementation of succession planning practices. few such studies exist, and it gives the strong evidence for importance of succession planning in education, health, and family business.

\section{Discussion and Conclusion}

Although succession planning is very complicated and lengthy process, however it is the imperative systematic method for organizational boom and viability. Effective succession plan assures smoother operations for unexpected and expected departs. Actions must be taken for earlier retirements. Transitions in the leadership often may cause inconsistency. Sometimes succession plans fail in some organization because organization do not involve employees during succession plan process. Employees in the business enterprise may additionally or may also now not be aware of succession planning process. Succession planning is more fantastic when it is obvious for all employees. Transparency in succession planning procedure must be make sure for a smooth transition. Therefore, human resources department is responsible for the communication of organizations succession to support employee's engagement. It is vital for personnel to be aware of succession planning process. Organizations no longer design successors in secret.

The most common succession planning practices were identified by the famous researchers which are individual development plans, technology advancement, involvement of future leaders, talent pool which can be used in any organization. Leadership development programs is appeared in the large organizations; however, small organizations need to develop their leaders. Some researchers suggested implementation of some more succession planning practices include transparency of succession planning process, communication expectations, diversity management and annual talent review for future successor.

The findings of this study will help all organizations to implement best succession planning practices which can allow their employees to grow professionally. Succession planning in the form of individual career development plans, internally groomed candidates will allow employees to feel that organization cares about them for their career progression. The absence of comprehensive model for succession planning in any organization is unfortunate. The key findings of this study are to publish succession planning best practices model which can be followed by all type of organizations.

\section{Recommendations}

Succession planning is the only effective when the top management support the individual development programmes for all employees. Technology advancement has provided significant ways to enhance organizational recruitments. Succession planning programmes requires enough financial support for training and development opportunities. Unfortunately, some organizations are often under strict budget conditions. Budget cuts can add element of complexity. This study is recommends for future researchers to focus on more succession planning practices such as technology advancement, budget allocation for succession planning programmes, communication, and transparency for succession planning process. Technological advancements will impact the way 
succession planning is implemented for future opportunities. Financial support from top management will also affect positively for effective implementation of succession programmes. Moreover, this study discussed how the organizations would implement succession planning practices in retaining top leadership talent as well middle management talent.

\section{References}

Aswathappa, K. (2013). Human resource management: Text and cases. Tata McGraw-Hill Education.

Asamani, J. A., Kwafo, E. O., \& Ansah-Ofei, A. M. (2013). Planning among nurse managers in district hospitals in Ghana.

Armstrong J. (1982) The value of formal planning for strategic decisions: review of empirical research. Strategic Management Journal. 3, 3, 197-211.

Arokiasamy, L., Omar, S.S., Ramlan, R., Balaraman, R.A. (2015) Competence development on academic career advancement at Malaysian private universities: An empirical study from human resource development perspective. Proceedings of the 26th International Business Information Management Association Conference - Innovation Management and Sustainable Economic Competitive Advantage: From Regional Development to Global Growth, IBIMA 2015

Bolander, P., Werr, A., \& Asplund, K. (2017). The practice of talent management: a framework and typology. Personnel Review, 46(8), 1523-1551.

Burgelman, R. A., \& Grove, A. S. (2007). Let chaos reign, then rein in chaos-repeatedly: Managing strategic dynamics for corporate longevity. Strategic management journal, 28(10), 965-979.

Baruch, Y., \& Peiperl, M. (200o). Career management practices: An empirical survey and implications. Human resource management, 39(4), 347-366.

Coleman, B. P. (1970). An integrated system for manpower planning. Business Horizons, 13(5), 89-95.

Dessler G (1997). Human Resource Management. Prentice Hall, Upper Saddle River, NJ.

Egan, R. F., Sarros, J. C., \& Santora, J. C. (1995). Putting transactional and transformational leadership into practice. Journal of Leadership Studies, 2(3), 100-123.

Employees. International Journal of Applied Research, 1(4), 177-178.

Eissa, N., \& Liebman, J. B. (1996). Labor supply response to the earned income tax credit. The quarterly journal of economics, $111(2), 605-637$.

Eskierka, J. A. (2011). Proposing a Succession Planning and Leadership Development Program for the St. Paul Fire Department (Doctoral dissertation, The College of St. Scholastica).

Eugene Fibuch, M. D., \& Van Way III, C. W. (2012). Succession planning in health care organizations. Physician Executive, 38(5), 44 .

Fulmer, R. (2004). Choose tomorrow's leaders today: Succession planning grooms firms for success. Retrieved from http://gbr.pepperdine.edu/o21/succession.html.

Gray, D. (2014). Succession planning 101. Professional Safety, 59(3), 35.

Grossman, C. S. (2014). Succession planning and knowledge transfer in higher education. Northcentral University.

Jamieson, D. W., \& Rothwell, W. J. (2016). The convergence of organization development and human resource management. Practicing Organization Development.

Kim, Y. (2010). Measuring the value of succession planning and management: A qualitative study of multinational companies. Performance Improvement Quarterly, 23(2), 5-31.

Kingsberry, F. (2017). $3 C_{1}$. The Role of Community Support in Navigating the Superin tendency for African American Women.

Mateso, P. E. (2010). Understanding succession planning and management efforts at Midwestern University: A mixed methods study (Doctoral dissertation, Bowling Green State University).

Mehrabani, S. E., \& Mohamad, N. A. (2011). Succession planning: A necessary process in today's organization. International Journal of e-Education, e-Business, e-Management, and e-Learning, 1(5), 371.

Hanson, B. (2013). The leadership development interface: Aligning leaders and organizations toward more effective leadership learning. Advances in Developing Human Resources, 15, 106-120. doi:10.1177/1523422312465853

Hess, J., \& Bacigalupo, A. (2013). Applying emotional intelligence skills to leadership and decision making in nonprofit organizations. Administrative Sciences, 3(4), 202-220.

Ibarra, P. (2005). Succession planning. Public Management, 87(1), 18-24.

Jones, S., Deckers, C. M., Strand, D., Bissmeyer, H., Bowman, W. J. W., \& Mathe, D. G. (2017). Succession planning: Creating a case for hiring new graduates. Nursing Economics, 35(2), 64-87. 
Kesner, I. F., \& Sebora, T. C. (1994). Executive succession: Past, present \& future. Journal of management, 20(2), 327-372.

L. L. Zaich, "Executive succession planning in select financial institute," Ph.D. dissertation, Pepperdine University, Malibu, CA, USA, 1986.

Payne, R. A., Hovarter, R., Howell, M., Draws, C., \& Gieryn, D. (2018). Succession Planning in Public Health: Addressing Continuity, Costs, and Compliance. Nurse Leader, 16(4), 253-256.

Peters-Hawkins, A. L., Reed, L. C., \& Kingsberry, F. (2018). Dynamic leadership succession: Strengthening urban principal succession planning. Urban Education, 53(1), 26-54.

Perrenoud, A. J., \& Sullivan, K. T. (2017). Analysis of executive succession planning in 12 construction companies. International Journal of Construction Education and Research, 13(1), 64-80.

Rothwell, W. J. (2005). Effective Succession Planning: Ensuring Leadership Continuity and Building Talent from Within. 3rd ed. New York AMACOM.

Rothwell, W. J. (2010). Effective Succession Planning: Ensuring Leadership Continuity and Building Talent from Within. 4th ed. New York: AMACOM.

Rothwell, W. (2010). Effective succession planning: Ensuring leadership continuity and building talent from within. Amacom.

Seniwoliba, J. A. (2015). Succession planning: Preparing the next generation workforce for the University for Development Studies.

Shipman, F. B. (2007). Formal succession planning in healthcare organizations: Meeting leadership needs in a changing American workforce. Spalding University.

Stroud, G. B. (2005). Succession plans and their effect on the promotions of women (Doctoral dissertation, Capella University).

Trow, D. B. (1961). Executive succession in small companies. Administrative science quarterly, 228-239.

Wiesman, J. M. (2012). Succession planning and management practice in Washington State local public health agencies: The current situation and recommendations for better practice (Doctoral dissertation, The University of North Carolina at Chapel Hill). 